Jacek Kulicki ${ }^{\mathrm{a}}$, Zofia Szpringer ${ }^{\mathrm{b}}$, Marek Jaśkowskic

\title{
Ocena zmienionego wniosku dotyczącego decyzji Rady w sprawie systemu zasobów własnych Unii Europejskiej ${ }^{1}$
}

\author{
Assessment of the amended proposal for a Council Decision on the System \\ of Own Resources of the European Union
}

The purpose of the proposed decision is to raise the limit of the annual own resources in relation to the national income (GNI) of the EU Member States and to empower the Commission to borrow up to EUR 750 billion at 2018 prices on the capital markets on behalf of the EU. These borrowed funds would be dedicated solely to combating the consequences of the COVID-19 pandemic. According to the authors of the opinion, the proposal is valid and rational from the perspective of protection and development of the internal market as an important Community element and does not raise doubts as to its compliance with the principle of subsidiarity. Its compatibility with Article 310 TFEU may however be disputed.

Keywords: budget, budget deficit, coronavirus, European Union

Celem projektowanej decyzji jest podniesienie pułapu rocznych zasobów własnych w odniesieniu do dochodu narodowego (DNB) państw członkowskich UE oraz upoważnienie Komisji do zaciągnięcia w imieniu UE pożyczek na rynkach kapitałowych do wysokości 750 mld euro w cenach z 2018 r. Środki te mają służyć wyłącznie zwalczaniu skutków pandemii COVID-19. Zdaniem autorów opinii projekt jest uzasadniony i racjonalny z punktu widzenia ochrony i rozwoju rynku wewnętrznego jako istotnego elementu wspólnotowego oraz nie budzi wątpliwości co do zgodności z zasadą pomocniczości, jego zgodność z art. 310 ust. 1 TFUE jest natomiast dyskusyjna.

Słowa kluczowe: budżet, deficyt budżetowy, koronawirus, Unia Europejska

a Doktor nauk prawnych -

ekspert ds. finansów publicznych Biura Analiz Sejmowych Kancelaria Sejmu, Wydział Analiz Społecznych i Ekonomicznych, Zespół Studiów Ekonomicznych, WARSZAWA, POLSKA -

jacek.kulicki@sejm.gov.pl • https://orcid.org/0000-0003-2631-6428

b Doktor nauk ekonomicznych -

naczelnik Wydziału Analiz Społecznych i Ekonomicznych w Biurze Analiz

Sejmowych, Kancelaria Sejmu, Biuro Analiz Sejmowych, Wydział Analiz Społecznych

i Ekonomicznych, WARSZAWA, POLSKA •

zofia.szpringer@sejm.gov.pl • https://orcid.org/0000-0002-8265-4440

$1 \quad$ Opinia w sprawie zmienionego wniosku dotyczącego decyzji Rady w sprawie systemu zasobów własnych Unii Europejskiej (COM(2020) 445 final) sporządzona 14 lipca 2020 r. na zlecenie Przewodniczącego Komisji do Spraw Unii Europejskiej; BAS-WASiE/ WAPM-1350/20. 
Doktor nauk prawnych, adiunkt -

Uniwersytet Kardynała Stefana Wyszyńskiego w Warszawie, Wydział Prawa

i Administracji, Katedra Prawa Międzynarodowego i Europejskiego, WARSZAWA,

POLSKA -

m.jaskowski@uksw.edu.pl • https://orcid.org/0000-0001-6598-810X

\section{Opinia merytoryczna}

\section{Przedmiot dokumentu UE}

\section{- Cel i treść dokumentu UE}

Przedmiotem oceny jest zmieniony wniosek Komisji dotyczący decyzji Rady w sprawie systemu zasobów własnych Unii Europejskiej (COM(2020) 445 final; dalej: projekt).

Celem projektowanej decyzji jest podniesienie pułapu rocznych zasobów własnych w odniesieniu do dochodu narodowego (DNB) państw członkowskich UE oraz upoważnienie Komisji do zaciągnięcia w imieniu UE pożyczek na rynkach kapitałowych do wysokości 750 mld euro w cenach z 2018 r.

Projekt zakłada zmianę wcześniejszego wniosku (zob. COM(2018) 325 final) $\mathrm{w}$ pięciu aspektach.

Po pierwsze, zawiera upoważnienie do zaciągnięcia przez Komisję w imieniu UE pożyczek na rynkach kapitałowych do wysokości 750 mld euro w cenach z 2018 r., które to środki będą mogły być wykorzystane - jako nadzwyczajny i tymczasowy środek służący finansowaniu działań przeciwdziałających kryzysowi związanemu z COVID-19 - na pożyczki dla państw członkowskich do wysokości 250 mld euro oraz na wydatki (wsparcie bezzwrotne dla państw członkowskich) do wysokości 500 mld euro w cenach z 2018 r., a także zasady spłaty tej pożyczki (nowy art. 3b),

Po drugie, wprowadza zasadę zabraniającą wykorzystywania przez UE środków pożyczonych na rynkach kapitałowych do finansowania wydatków operacyjnych (nowy art. 3a), z tym że z zasady tej wyłączone mają być pożyczki zaciągnięte w celu złagodzenia skutków kryzysu związanego z COVID-19 (art. 3b pkt 1 lit. b),

Po trzecie, w projekcie zaproponowano zwiększenie o 0,11 pkt proc. pułapu środków na pokrycie zobowiązań i płatności, odpowiednio z 1,35\% do 1,46\% (zobowiązania) i z 1,29\% do 1,40\% (płatności) DNB wszystkich państw członkowskich (zmiana art. 3 ust. 1 i 2 pierwotnego projektu decyzji),

Po czwarte, projekt zawiera uregulowanie podwyższające czasowe limity (pułapy) środków własnych opartych na DNB o 0,6 pkt proc. w celu pokrycia wszystkich zobowiązań UE wynikających z zaciągniętych pożyczek na złagodzenie skutków kryzysu gospodarczego, aż do momentu wygaśnięcia wszystkich tych zobowiązań, najpóźniej do 31 grudnia 2058 r. (nowy art. 3c), 
Po piąte, wprowadza zasadę zobowiązującą państwa członkowskie do udostępnienia Komisji niezbędnych zasobów w celu spłaty zaciągniętych przez UE pożyczek, jeżeli środki zapisane w budżecie okażą się niewystarczające do wypełnienia przez UE tych zobowiązań (nowy ust. $4 \mathrm{w}$ art. 6).

Pozostałe regulacje pierwotnego wniosku pozostają bez zmian (określenie kategorii zasobów własnych, w tym propozycja włączenia do nich zasobów opartych na podatku dochodowym od przedsiębiorstw, unijnym systemie handlu uprawnieniami do emisji, odpadach opakowaniowych z tworzyw sztucznych, obniżki i rabaty dla państw członkowskich, przenoszenie nadwyżki dochodów nad wydatkami występującej w roku budżetowym na następny rok budżetowy, pobór zasobów własnych UE, zakres środków wykonawczych związanych z zasobami własnymi UE) ${ }^{2}$.

\section{- Geneza dokumentu UE}

Przedstawiony przez Komisję wniosek związany jest z kryzysem zdrowia publicznego wywołanym przez COVID-19 oraz będącym jego skutkiem kryzysem gospodarczym prowadzącym - według szacunków Komisji - do obniżenia PKB UE w 2020 r. o ok. 7,5\% i wzrostu bezrobocia do 9\%, czemu towarzyszy ryzyko pogłębienia się ubóstwa i nierówności.

Zdaniem Komisji zaproponowane rozwiązanie (zaciągnięcie pożyczki na rynkach kapitałowych przez UE jako całość i rozłożenie jej spłaty na co najmniej 31 lat, począwszy od 1 stycznia 2028 r.) stanowi uzupełnienie dyskrecjonalnych środków gospodarczych i finansowych podejmowanych przez państwa członkowskie w celu przeciwdziałania negatywnym skutkom pandemii COVID-19. Upoważnienie Komisji do zaciągnięcia w imieniu UE pożyczek na rynkach kapitałowych umożliwi znaczne zwiększenie środków finansowych w celu wsparcia odbudowy potencjału gospodarczego UE.

\section{- Informacja o stanie prawa obowiązującego w Polsce w materii objętej treścią dokumentu UE}

Przyjęcie projektowanych zmian w zakresie systemu zasobów własnych Unii Europejskiej nie wywołuje bezpośrednich skutków legislacyjnych.

Po przyjęciu przez Radę decyzja będzie podlegała ratyfikacji zgodnie z wymogami Konstytucji RP.

2 Zob. opinia BAS z 13 czerwca 2018 r. odnoszącą się do wniosku dotyczącego decyzji Rady w sprawie systemu zasobów własnych Unii Europejskiej (COM(2018) 325 final), sygn. BAS-WASiE/WAPM-1197/18, http://www.sejm.gov.pl/sejm8.nsf/EDLS.xsp?vie $\mathrm{w}=1 \&$ docId=4A5A5CC2AD00F508C12584A80039B33D\&lang=PL [dostęp: 3 lipca 2020 r.]. 


\section{Ocena dokumentu UE}

\section{- Ocena skutków dokumentu UE}

Projektowana decyzja wprowadza istotne zmiany do pierwotnego projektu decyzji dotyczącej zasobów własnych UE, która ma zagwarantować środki na realizację wydatków w ramach perspektywy finansowej na lata 2021-2027 (zob. $\operatorname{COM}(2018) 325$ final). W istocie dotyczą one dwóch zasadniczych elementów. Po pierwsze, podniesienia wkładu państw członkowskich opartego na DNB (zmiana ust. 1 i $2 \mathrm{w}$ art. 3), po drugie, zwiększenia środków UE przez zaciągnięcie pożyczek na rynkach kapitałowych (nowy art. 3b).

O ile zwiększenie środków UE przez zaciągnięcie pożyczek na rynkach kapitałowych stanowi nadzwyczajny i tymczasowy instrument finansowy, o tyle podniesienie wkładu państw członkowskich w odniesieniu do DNB ma charakter stały. Zauważyć przy tym należy, że regulacja dotycząca wpłat własnych państw członkowskich opartych na DNB zawarta jest w dwóch przepisach. Pierwszy (art. 3 ust. 1 i 2) odnosi się do określenia łącznej kwoty zasobów własnych przydzielonych UE na pokrycie rocznych środków na płatności i zobowiązania, jako elementu stałego kształtującego system zasobów własnych UE. Zgodnie z propozycją Komisji zarówno limit na płatności, jak i limit na zobowiązania mają być podniesione o 0,11 pkt proc.: dla płatności z 1,29\% do 1,40\% DNB wszystkich państw członkowskich (art. 3 ust. 1), dla zobowiązań z 1,35\% do 1,46\% DNB wszystkich państw członkowskich (art. 3 ust. 2). Ta zmiana, jak wynika z nowego motywu 13a, ma na celu zachowanie ,wystarczającego marginesu w ramach pułapów wskazanych w decyzji w sprawie zasobów własnych, tak aby Unia mogła pokryć wszystkie swoje zobowiązania finansowe i warunkowe, których termin zapadalności przypada na dany rok" i jest związana po części z przewidywanym spowolnieniem gospodarczym wynikającym z COVID-19. Niemniej należy zauważyć, że jeżeli propozycja podwyższenia limitu wpłat opartych na DNB związana jest jedynie z przewidywanym spowolnieniem gospodarczym, to projekt powinien zawierać - w przypadku powrotu do stanu sprzed wybuchu epidemii COVID-19 - mechanizm umożliwiający powrót do pierwotnych limitów. Jest to o tyle uzasadnione, że projekt zawiera dwie następne regulacje dotyczące wpłat państw członkowskich. Obie związane są z upoważnieniem Komisji do zaciągnięcia w imieniu UE pożyczek na rynkach kapitałowych w celu sfinansowania walki ze skutkami pandemii COVID-19. Pierwsza polega na czasowym podwyższeniu (o 0,6 pkt proc.) wkładu państw członkowskich opartego na DNB (art. 3c), druga zobowiązuje państwa członkowskie do udostępnienia Komisji niezbędnych zasobów w celu spłaty zaciągniętych przez UE pożyczek, jeżeli środki zapisane w budżecie okażą się niewystarczające do wypełnienia przez UE tych zobowiązań (nowy ust. $4 \mathrm{w}$ art. 6). Kwoty te mogą być przeznaczone wyłącznie na pokrycie zobowiązań UE z tytułu zaciągniętych pożyczek. Tym samym przepisy dotyczące zasobów własnych UE gwarantują środki na spłatę zobowiązań UE z tytułu za- 
ciągniętych przez nią pożyczek. Dodatkowy margines w tym zakresie wydaje się w przypadku powrotu wzrostu gospodarczego zbędny, o ile UE nie będzie chciała przeznaczyć ich na inne cele niż spłatę zobowiązań związanych z zaciągniętymi pożyczkami.

W odniesieniu do zwiększenia środków UE przez zaciągnięcie pożyczek na rynkach kapitałowych należy zauważyć, że możliwość taka ma mieć charakter nadzwyczajny i tymczasowy. Środki te mogą służyć wyłącznie celom złagodzenia skutków kryzysu związanego z COVID-19. W decyzji określono jedynie, co zrozumiałe w przypadku decyzji dotyczącej dochodów budżetowych, limit pożyczek (750 mld euro), kwotę przeznaczoną na pożyczki dla państw członkowskich (250 mld euro) i wydatki stanowiące pomoc bezzwrotną dla państw członkowskich (500 mld euro), zasadę spłaty pożyczki i odsetek z budżetu ogólnego UE, zasadę planowości, zasadę należytego zarządzania finansami, okres spłaty pożyczki (od 1 stycznia 2028 r. do 31 grudnia 2058 r.), roczny limit spłaty kwoty głównej (7,5\% kwoty pożyczki, którą UE może maksymalnie zaciągnąć).

Upoważnienie do zaciągnięcia pożyczki należy ocenić przede wszystkim w kontekście zasad traktatowych. Zgodnie z art. 311 akapit pierwszy traktatu o funkcjonowaniu Unii Europejskiej (TFUE) Unia pozyskuje środki niezbędne do osiągnięcia swoich celów i należytego prowadzenia swoich polityk. Jednym $\mathrm{z}$ celów UE jest ustanowienie jednolitego rynku (art. 3 ust. 3 traktatu o Unii Europejskiej,TUE), a więc obszaru bez granic wewnętrznych, w którym jest zapewniony swobodny przepływ towarów, osób, usług i kapitału, zgodnie z postanowieniami traktatowymi (art. 26 ust. 2 TFUE). Pandemia COVID-19 niewątpliwie stanowi istotne zagrożenie dla funkcjonowania rynku wewnętrznego, swobody przepływu przede wszystkim towarów, osób i usług. Z tego względu UE ma obowiązek podejmować działania przeciwdziałające erozji rynku wewnętrznego, nie tylko spadku DNB, ale również powodującego wszelkie formy wykluczenia obywateli UE i przedsiębiorstw, będącego następstwem nie tylko czynników obiektywnych, związanych w tym przypadku z pandemią COVID-19, ale również protekcjonistycznej polityki poszczególnych państw członkowskich chroniących swoje rynki. Ochrona rynku wewnętrznego jako istotnego elementu wspólnotowego wymaga odpowiednich środków finansowych, które będą mogły być przeznaczone na cele przeciwdziałania skutkom pandemii COVID-19. Zaproponowane regulacje środki takie zapewniają. $Z$ tego punktu widzenia projektowane rozwiązanie należy uznać za uzasadnione i racjonalne. Warto przy tym wskazać, że zaciągnięta pożyczka będzie zobowiązaniem długoterminowym i obciąży budżet UE i budżety państw członkowskich przez kilka perspektyw finansowych (do końca 2058 r.). W związku z tym słusznie wskazano w projekcie stanowiska rządu RP, że: „Istotną słabością propozycji jest brak uwzględnienia źródeł finansowania spłaty pożyczek, która ma nastąpić od początku $2028 \mathrm{r}$. Zapowiedź KE, iż spłata pozyskanych środków nastąpi z przyszłych budżetów długoterminowych w formie m.in. nowych zasobów własnych, zwiększonych 
składek krajowych, refinansowania pożyczek, ograniczenia polityk lub kombinacji tych możliwości, nie pozwala na obecnym etapie na ocenę, czy składki na pokrycie zobowiązań będą w sposób sprawiedliwy obciążały wszystkie państwa członkowskie, co jest bardzo istotne dla Polski”.

Odrębną kwestią jest podział między państwa członkowskie środków pochodzących z pożyczek oraz cele, na jakie te środki będą mogły być przeznaczone, co nie jest przedmiotem opiniowanej decyzji i powinno podlegać szczególnej kontroli parlamentarnej.

Możliwość zaciągnięcia pożyczek na rynkach kapitałowych oznaczać może odejście od ważnej zasady zrównoważonego budżetu unijnego. Do tej pory bowiem dochody tego budżetu, w których dominowały środki pochodzące ze składek państw członkowskich, tzw. zasoby własne UE, musiały odpowiadać wydatkom (środkom na płatności). Potrzeba zaciągania pożyczek wynika $\mathrm{z}$ tego, że zakłada się, iż w danym okresie wieloletnich ram finansowych 2021-2027 brakować będzie wystarczających dochodów na pokrycie zaplanowanych wydatków na złagodzenie skutków kryzysu związanego z COVID-19, stąd brakujące środki należy pozyskać na rynku. Jest to $\mathrm{w}$ istocie zaciągnięcie długu, który wraz z należnymi odsetkami będą musiały spłacić państwa członkowskie. Obecnie nie wiadomo dokładnie, według jakich zasad to nastąpi, ale niewątpliwie takie działanie może pociągać za sobą różne ryzyka (np. wynikające ze zmian stóp procentowych czy kursu walutowego) i być obciążeniem dla przyszłych pokoleń.

W zakresie regulacji zawartych w pierwotnym projekcie decyzji dotyczącej zasobów własnych UE, niezmienionych opiniowanym projektem, aktualne pozostają uwagi BAS zawarte w przywołanej wyżej opinii z 13 czerwca 2018 r. $^{3}$.

\section{- Ocena zgodności działań UE, o których mowa w dokumencie UE, z zasadą pomocniczości}

Co prawda opiniowany dokument podlega ocenie parlamentów narodowych pod względem zgodności z zasadą pomocniczości w trybie określonym w protokole (nr 2), jednak zaznaczyć należy, że państwa członkowskie Unii Europejskiej, każde odrębnie, nie dysponują kompetencją do określenia poszczególnych kategorii zasobów własnych UE. Zgodnie z art. 311 akapit pierwszy TFUE Unia pozyskuje środki niezbędne do osiągnięcia swoich celów i należytego prowadzenia swoich polityk. Akapit drugi tego artykułu stanowi, że budżet UE finansowany jest z zasobów własnych. Określenie poszczególnych kategorii zasobów własnych UE należy do kompetencji Rady i wchodzi w życie po zatwierdzeniu przez państwa członkowskie zgodnie z ich wymogami konstytucyjnymi.

Tym samym należy uznać, że projekt decyzji Rady w sprawie zasobów własnych Unii Europejskiej jest zgodny z zasadą pomocniczości.

3 Ibidem. 


\section{- Ustosunkowanie się do projektu stanowiska RP}

Rząd w projekcie stanowiska RP, przyjętym 10 czerwca 2020 r., popiera zawarte w projekcie zmian decyzji propozycje odnoszące się do możliwości zaciągnięcia przez UE pożyczek na rynkach kapitałowych w celu zapewnienia dodatkowych środków finansowych dla budżetu UE w związku z COVID-19. Rząd RP uznaje za uzasadnione rozłożenie spłaty tych zobowiązań na jak najdłuższy okres (do 2058 r.) oraz popiera nadzwyczajne i tymczasowe podniesienie pułapu zasobów własnych o 0,6 pkt proc. DNB UE w celu pokrycia wszystkich zobowiązań UE wynikających z zaciągniętych pożyczek w związku z COVID-19.

Rząd RP popiera również stałe podniesienie pułapu zasobów własnych do poziomu 1,40\% DNB UE-27 (dla płatności) i 1,46\% (dla zobowiązań), co ma stanowić gwarancję wywiązywania się przez UE z jej zobowiązań.

Rząd RP również pozytywnie ocenia ujęcie w decyzji zasady, zgodnie z którą wydatki operacyjne budżetu UE nie są finansowane z pożyczek, co nadaje uprawnieniu Komisji do zaciągania pożyczek charakter nadzwyczajny i jednorazowy.

Rząd RP ocenia, że łączne koszty spłaty kapitału w ramach pożyczki w kwocie 500 mld euro wynosiłyby w przypadku Polski - w zależności od zakładanego poziomu wzrostu gospodarczego - od ok. 21,5 mld euro do 25,0 mld euro w cenach stałych z 2018 r.

Stanowisko to jest uzupełnieniem stanowiska Polski przyjętego wobec propozycji zmiany decyzji w sprawie systemu zasobów własnych UE z 4 maja 2018 r., z uwzględnieniem dotychczasowych postępów negocjacyjnych.

Stanowisko rządu dotyczące opiniowanej decyzji, wyrażone w projekcie stanowiska RP, nie budzi zastrzeżeń.

\section{- Wniosek dotyczący działań przedstawiciela RP w odniesieniu do dokumentu UE}

Przedłożony projekt zasługuje na poparcie przez przedstawiciela Polski na forum Rady UE.

\section{Opinia prawna}

\section{Podstawa prawna dokumentu UE}

\section{- Wskazanie podstawy prawnej dokumentu UE}

Decyzja ma zostać przyjęta na podstawie art. 311 akapit trzeci TFUE, oraz art. 106a Traktatu ustanawiającego Europejską Wspólnotę Energii Atomowej (TEWEA), który stanowi, że wymienione w nim przepisy zawarte w TUE i TFUE (w tym art. 311 TFUE), stosuje się do TEWEA.

Zgodnie $\mathrm{z}$ art. 311 TFUE Rada przyjmuje decyzję określającą przepisy mające zastosowanie do systemu zasobów własnych Unii. W tym kontekście można 
ustanawiać nowe lub uchylać istniejące kategorie zasobów własnych. Artykuł 311 TFUE wymaga zastosowania specjalnej procedury ustawodawczej, przyjęta $\mathrm{w}$ tym trybie decyzja będzie więc miała rangę aktu ustawodawczego.

\section{- Ocena legalności dokumentu UE}

Artykuł 310 ust. 1 TFUE przewiduje, że wszystkie dochody i wydatki Unii powinny być wpisane do budżetu (zasada jedności budżetu UE) oraz że budżet UE powinien być zrównoważony w odniesieniu do dochodów i wydatków (zasada zrównoważonego budżetu UE). Zasady te zostały uszczegółowione w rozporządzeniu finansowym $\mathrm{UE}^{4}$, które stanowi, że w budżecie na każdy rok budżetowy prognozowane są i zatwierdzane wszystkie dochody i wydatki uznane za niezbędne dla Unii (art. 7 ust. 1) oraz że dochody i środki na płatności muszą znajdować się w równowadze, a Unia oraz jej organy nie mogą zaciągać pożyczek w ramach budżetu (art. 17).

Opiniowany dokument nie jest co prawda projektem budżetu, jednak z uwagi na przewidzianą w projektowanym art. 3b możliwość zaciągnięcia przez Komisję w imieniu Unii pożyczek, które następnie miałyby być spłacane z budżetu ogólnego Unii, należy ocenić, czy jest on zgodny z zasadami wskazanymi w poprzedzającym akapicie. Problem ten został co prawda pominięty przez Komisję Europejską w uzasadnieniu projektu, jednak KE ustosunkowała się do tych wątpliwości w dokumencie Pytania i odpowiedzi: Next Generation EU - konstrukcja prawna z 9 czerwca 2020 r. ${ }^{5}$ (dalej: konstrukcja prawna). Zagadnienie zostało również dostrzeżone i poddane głębszej analizie w opinii Służby Prawnej Rady (dalej: SPR) ${ }^{6}$.

Zdaniem KE „pożyczone środki stanowią wyjątkowe i jednorazowe kwoty mające charakter dodatkowy do budżetu rocznego jako zewnętrzne dochody przeznaczone na określony cel (na wydatki) i nie stanowią one części dochodów ani wydatków w ramach budżetu rocznego”. Zaciągnięcie pożyczek miałoby być zgodne z ograniczeniami określonymi w art. 310 TFUE, ponieważ „decyzja

4 Rozporządzenie Parlamentu Europejskiego i Rady (UE, Euratom) 2018/1046 z 18 lipca 2018 r. w sprawie zasad finansowych mających zastosowanie do budżetu ogólnego Unii, zmieniające rozporządzenia (UE) nr 1296/2013, (UE) nr 1301/2013, (UE) nr 1303/2013, (UE) nr 1304/2013, (UE) nr 1309/2013, (UE) nr 1316/2013, (UE) nr 223/2014 i (UE) nr 283/2014 oraz decyzję nr 541/2014/UE, a także uchylające rozporządzenie (UE, Euratom) nr 966/2012, Dz.Urz. UE L 193, 30 lipca 2018 r., s. 1.

$5 \quad$ Https://ec.europa.eu/commission/presscorner/detail/en/qanda_20_1024.

6 Opinia Służby Prawnej Rady UE z 24 czerwca 2020 r., 9062/20: Proposals on Next Generation EU Compatibility of the package with the Union's principles of budgetary balance and discipline under Article 310 TFEU Compatibility of the package with the integrity of the system of own resources (Article 311 TFEU) Suitability of Article 122 TFEU as legal basis for the Recovery Instrument proposal Compatibility of the package with Article 125(1) TFEU (no bail-out clause). Opinia, pierwotnie objęta klauzulą „LIMITE”, została upubliczniona 3 lipca 2020 r. (zob. dokument ST 90622020 COR 1). 
w sprawie zasobów własnych będzie już gwarantować środki finansowe potrzebne na spłatę pożyczek”. Komisja przekonuje, że w istocie „państwa członkowskie zgadzają się na udostępnienie zasobów finansowych Unii, ale ponieważ obecnie dysponują tylko ograniczoną przestrzenią fiskalną, „odraczają” czy też „opóźniają” to „udostępnienie”. Podobne stanowisko zajęła SPR (pkt 46 jej opinii), uznając, że pożyczone kwoty zostaną przekazane na dane wydatki jako „zewnętrzne dochody przeznaczone na określony cel (external assigned revenue)". Jako takie $\mathrm{z}$ natury mają charakter dodatkowy i z budżetowego punktu widzenia nie pociągają za sobą konsekwencji w postaci nierównowagi budżetowej. Ponadto zwrot długu zaciągniętego przez UE ma być gwarantowany dzięki zarezerwowaniu na ten cel środków, do wniesienia których państwa członkowskie będą zobowiązane na mocy projektowanej decyzji. Jednocześnie, oceniając zgodność takiego podejścia z zasadą jedności budżetu UE, SPR uznała m.in., że:

- projekt jest proponowany jako wyjątkowy, tymczasowy i jednorazowy instrument mający na celu ożywienie gospodarcze w duchu solidarności, będącej podstawową zasadą leżącą u podstaw traktatów,

- do prawodawcy Unii należy ustalenie, jakie środki finansowe są niezbędne do właściwej realizacji celu; w tym zakresie ma on margines swobody, który obejmuje możliwość skorzystania z pożyczki, która stanowi zewnętrzne dochody przeznaczone na określony cel; ten margines swobody jest jednak ograniczony koniecznością poszanowania integralności systemu zasobów własnych Unii,

- ze względu na znaczną kwotę, którą reprezentowałyby zewnętrzne dochody przeznaczone na proponowany cel, należy zapewnić odpowiednie zabezpieczenia w celu ochrony integralności systemu zasobów własnych Unii i systemu budżetowego; wyjątkowy charakter kryzysu, jednorazowy charakter i ograniczony czas trwania proponowanych rozwiązań, co odzwierciedlono w poszczególnych wnioskach, stanowią takie odpowiednie zabezpieczenia ${ }^{7}$.

Powyższa argumentacja Komisji i SPR zmierza do wykazania zgodności projektu z art. 310 TFUE. Należy jednak zauważyć, że opiniowany projekt ma na celu umożliwienie zaciągnięcia pożyczek, które miałyby w znacznym stopniu zostać wykorzystane do finansowania działalności operacyjnej UE i które byłyby spłacane $\mathrm{z}$ unijnego budżetu. W tym zakresie projekt może budzić wątpliwości co do zgodności z ograniczeniami wynikającymi z art. 310 ust. 1 akapit 3 TFUE.

Potraktowanie całej operacji jako czegoś zewnętrznego w stosunku do budżetu UE może wywołać wątpliwości co do zgodności z zasadą jedności budżetu UE, wyrażoną w art. 310 ust. 1 akapit 1 TFUE. Wskazane wyżej argumenty zawarte w opinii SPR w dużej mierze odnoszą się do wyjątkowego charakteru proponowanych środków. Nie jest to jednak argumentacja, która w sposób kompleksowy rozstrzyga o dopuszczalności proponowanych rozwiązań na płaszczyźnie prawnej.

\footnotetext{
$7 \quad$ Zob. szerzej pkt 63-70 opinii SPR.
} 
Konkludując, należy stwierdzić, że projekt może budzić wątpliwości co do zgodności z art. 310 ust. 1 TFUE ${ }^{8}$.

\section{Skutki prawne}

Zgodnie z art. 288 TFUE decyzja wiąże w całości. Poza określonymi w decyzji wyjątkami ma ona być stosowana od 1 stycznia $2021 \mathrm{r}$.

\section{Kwestie proceduralne}

\section{- Procedura przyjmowania dokumentu UE}

Pierwotny projekt decyzji został przyjęty przez Komisję 2 maja 2018 r. i tego samego dnia został przekazany do Rady i Parlamentu Europejskiego. Zmieniony projekt został przyjęty przez Komisję 28 maja 2020 r. i tego samego dnia został przekazany do Rady i Parlamentu Europejskiego. Dokument UE będzie przyjmowany przez Radę w specjalnej procedurze ustawodawczej. Rada stanowi jednomyślnie, po konsultacji z Parlamentem Europejskim.

Decyzja wchodzi w życie dopiero po jej zatwierdzeniu przez państwa członkowskie, zgodnie z ich odpowiednimi wymogami konstytucyjnymi. W prawie polskim wymóg ratyfikacji aktów prawnych Unii Europejskiej przyjętych na podstawie art. 311 akapit trzeci TFUE wynika z art. 12 ust. 2a ustawy z 14 kwietnia 2000 r. o umowach międzynarodowych (Dz.U. 2020, poz. 127).

Proponowana regulacja, jako projekt aktu ustawodawczego, jest przekazywana także parlamentom narodowym, zgodnie $\mathrm{z}$ art. 2 protokołu (nr 1) w sprawie roli parlamentów narodowych w Unii Europejskiej. Pierwotny projekt decyzji został przekazany Sejmowi w języku polskim 4 maja 2018 r., natomiast opiniowana modyfikacja - 28 maja 2020 r.

\section{- Działania Komisji ds. Unii Europejskiej}

Zgodnie z art. 7 ust. 1 ustawy z 8 października 2010 r. o współpracy Rady Ministrów z Sejmem i Senatem w sprawach związanych z członkostwem Rzeczypospolitej Polskiej w Unii Europejskiej (Dz.U. nr 213, poz. 1395; dalej: ustawa kooperacyjna) Rada Ministrów przekazuje Sejmowi projekty stanowisk Rzeczypospolitej Polskiej w sprawie projektów aktów ustawodawczych Unii Europejskiej, biorąc pod uwagę terminy wynikające z prawa Unii Europejskiej, nie później jednak niż w terminie 14 dni od dnia otrzymania tych projektów. Rada Ministrów przekazała Sejmowi projekt stanowiska RP odnoszący się do projektowanego aktu prawnego UE 10 czerwca 2020 r., dochowując terminu ustawowego.

8 Zob. podobnie P. Leino, Next Generation EU: Breaking a taboo or breaking the law?, CEPS in Brief, Centre for European Policy Studies, 2020, https://www.ceps.eu/next-generation-eu. 
Komisja ds. Unii Europejskiej może, działając w trybie art. 7 ust. 4 ustawy kooperacyjnej, wyrazić opinię o projekcie decyzji w terminie 49 dni od dnia przekazania Sejmowi projektu aktu UE. Jeżeli Komisja wyda we wskazanym trybie opinię, powinna ona stanowić podstawę stanowiska Rzeczypospolitej Polskiej (art. 13 ust. 1 ustawy kooperacyjnej). Termin na wyrażenie przez Komisję ds. Unii Europejskiej opinii o projekcie decyzji upływa więc 16 lipca 2020 r.

Zgodnie $\mathrm{z}$ art. 6 protokołu (nr 2) w sprawie stosowania zasad pomocniczości i proporcjonalności Sejm może, w terminie ośmiu tygodni od daty przekazania projektu aktu ustawodawczego w językach urzędowych Unii, przesłać przewodniczącym Parlamentu Europejskiego, Rady i Komisji uzasadnioną opinię zawierającą powody, dla których uznaje, że dany projekt nie jest zgodny z zasadą pomocniczości. Zgodnie z listem Sekretarza Generalnego Komisji Europejskiej wszystkie wersje językowe projektowanej decyzji zostały przekazane parlamentom narodowym oraz izbom parlamentów narodowych państw członkowskich 29 maja 2020 r. Termin na przesłanie uzasadnionej opinii w sprawie projektu rozporządzenia upływa zatem 24 lipca $2010 \mathrm{r}$.

W niniejszej sprawie Komisja ds. UE może więc wnieść projekt uchwały w sprawie uznania projektu aktu ustawodawczego UE za niezgodny z zasadą pomocniczości. W takim wypadku do projektu uchwały powinna być załączona uzasadniona opinia zawierająca powody, dla których Sejm uznaje, że projekt aktu ustawodawczego UE nie jest zgodny z zasadą pomocniczości (art. 148cc ust. 1 i 2 regulaminu Sejmu).

Zgodnie $\mathrm{z}$ informacją zamieszczoną w bazie IPEX do dnia sporządzenia niniejszej opinii uzasadniona opinia została przedłożona tylko przez parlament Szwecji (Riksdag). Uzasadnienie stanowiska parlamentu Szwecji zawiera argumenty nie ograniczające się do zasady pomocniczości, natomiast w zakresie, w jakim odnosi się do tej zasady, wskazuje, że nie zostało jasno uzasadnione, dlaczego pożyczki na ograniczenie skutków pandemii mają być zaciągane na poziomie UE, a nie państw członkowskich. Na marginesie warto zauważyć, że Riksdag przedłożył uzasadnioną opinię również w odniesieniu do pierwotnego projektu decyzji, tj. COM(2018) 325.

W ocenie Biura Analiz Sejmowych projekt nie budzi zastrzeżeń co do zgodności z zasadą pomocniczości (zob. podrozdział zatytułowany „Ocena zgodności działań UE, o których mowa w dokumencie UE, z zasadą pomocniczości” niniejszej opinii).

\section{Podsumowanie}

- Celem projektowanej decyzji jest podniesienie pułapu rocznych zasobów własnych w odniesieniu do dochodu narodowego UE oraz upoważnienie Komisji do zaciągnięcia w imieniu UE pożyczek na rynkach kapitałowych do wysokości 750 
mld euro w cenach z 2018 r., które to środki będą mogły służyć wyłącznie celom złagodzenia skutków kryzysu związanego z COVID-19.

- Projektowane rozwiązanie należy uznać za uzasadnione i racjonalne z punktu widzenia ochrony i rozwoju rynku wewnętrznego jako istotnego elementu wspólnotowego.

- Projekt nie budzi wątpliwości co do zgodności z zasadą pomocniczości.

- Przy odrzuceniu argumentacji Służby Prawnej Rady projekt może budzić wątpliwości co do zgodności z art. 310 ust. 1 TFUE. 